\title{
MOLYBDATE TRANSPORT IN THE Bradyrhizobium japonicum - Glycine max L. SYMBIOSIS
}

\author{
Á. Tresierra-Ayala ${ }^{1 *}$, M.J. Delgado ${ }^{2}$, R.A. Guzmán ${ }^{1}$, A.L. Rengifo ${ }^{1}$, and \\ E.J. Bedmar ${ }^{2}$ \\ ${ }^{1}$ Departamento Académico de Microbiología y Parasitología. Facultad de Ciencias Biológicas - \\ Universidad Nacional de la Amazonía Peruana, Iquitos, Perú. ${ }^{2}$ Departamento de Microbiología \\ del Suelo y Sistemas Simbióticos. Estación Experimental del Zaidín. Consejo Superior de \\ Investigaciones Científicas, Granada, España. \\ *Corresponding author: atresierraayala@hotmail.com
}

\begin{abstract}
For the molybdoenzymes synthesis as the nitrogenase, the molybdenum, in its most stable form, the molybdate, must be transported inside the cell. In Bradyrhizobium japonicum, the modABC genes code for a high-affinity ABC-type molybdate transporter. This work allowed to study the effect of inoculation of soybean plants with strains affected in the molybdate transport. $\bmod A$ and $\bmod B$ mutants, unable to grow in culture media under molybdate-deficient conditions, were used in our experiments. When soybean plants were inoculated with one of these strains and grown in a molybdate-deficient mineral solution did not affect the nodulation, but the nitrogenfixing ability of the mod mutants was severely impaired. Addition of molybdate to the nutrient mineral solution used for plant growth fully restaured the wild-type phenotype, and the amount of molybdate required for supression of the mutant phenotype was dependent on sulfate concentration. Molybdate concentration required for the functioning of the mutant strains was greater when the medium was supplemented with high amounts of sulfate. Our results suggest the existence in B. japonicum, at least, three independent molybdate transport systems, a high-affinity transporter encoded by the $\bmod A B C$ genes, a low affinity system corresponding to a sulfate transporter, and a third transporter that would be functional in the presence of high sulfate concentrations.
\end{abstract}

Keywords: soybean, Bradyrhizobium, mod genes, molybdate transport, nitrogenase.

\section{INTRODUCTION}

Soybean seed (Glycine max L., Fabaceae family) is one of the most nutritious legumes and of higher energy value, it contains about $37 \%$ of high-quality proteins, which is almost twice the meat proteins, four times the egg proteins and twelve times the milk proteins. It has $18 \%$ of unsaturated fat; vitamins A, E, F and B, and is one of the richest sources of lecithin, essential substance for the cells because it dissolves the bad cholesterol and helps the assimilation of vitamins (Arnau, 2009).

Soybean plant establishes symbiotic association with Bradyrhizobium japonicum, a bacterium that, like other species of the Rhizobiales order, is characterized by its ability to infect the 
roots of legumes and form nodules, specialized organs within which, as bacteroids, made the biological fixation of atmospheric nitrogen $\left(\mathrm{N}_{2}\right)$, or the reduction of nitrogen in ammonium $\left(\mathrm{NH}_{4}^{+}\right)$, a reaction catalyzed by nitrogenase (Lawson and Smith, 2002). This association enables the legumes to grow in soils of low fertility, with deficient in $\mathrm{N}$ combined, where other plants can not grow.

Molybdenum is an essential element for soil microorganisms, since it serves as a cofactor for different enzymes involved in the metabolism of nitrogen, carbon and sulfur. Before the synthesis of molybdoenzymes, uptake of molybdate (the more stable form of molybdenum, which in this study it will be called Mo), its activation to an appropriate form, and its incorporation into the organic fraction of the molybdenum-cofactors, are required (Pau and Lawson, 2002). In Escherichia coli, the incorporation of Mo is mediated by a high-affinity $\mathrm{ABC}$-type transport system, encoded by the $\bmod A B C$ genes. ModA protein binds Mo in the periplasm, ModB is a transmembrane component of the permease, and ModC provides the energizer function on the cytoplasmic side of the membrane (Grunden and Shanmugam, 1997; Self et al., 2001). Moreover, in this bacterium, uptake of Mo can be carried out by sulfate-transporter, a low-affinity system for Mo, which is encoded by the cysPTWA and sbp genes. The sbp product binds either sulfate or Mo, CysP recruits thiosulfate, CysT and CysW are permeases for sulfate/Mo transport, and CysA has ATPase activity (Sirko et al., 1990; Kertesz, 2001).

On the other hand, it has shown that cysteine inhibits the transport and use of sulfate in some bacteria (Stewart and MacGregor, 1982; Trudinger and Loughlin, 1982; Ugalde et al., 1985) and that the cysteine addition to the culture medium inhibited the mutation effects of modABC genes in K. pneumoniae strains (Ugalde et al., 1985). Because a mutant affected in both transport systems (Mo and sulfate) was still able to incorporate Mo, in presence of high concentrations of this element, Rosentel et al. (1995) suggested that in E. coli, a third transport system is involved in Mo uptake.

In B. japonicum, molybdenum is part of important proteins, including the nitrogenase, an molybdoenzyme that reduces atmospheric dinitrogen $\left(\mathrm{N}_{2}\right)$ into ammonia $\left(\mathrm{NH}_{4}^{+}\right)$(Lawson and Smith, 2002). This bacterium is also capable of denitrification, that is, the reduction of nitrate $\left(\mathrm{NO}_{3}^{-}\right)$to nitrite $\left(\mathrm{NO}_{2}{ }^{-}\right)$, via nitric oxide (NO) and nitrous oxide $\left(\mathrm{N}_{2} \mathrm{O}\right)$ to $\mathrm{N}_{2}$, when the cells are cultured under oxygen-limiting conditions (Bedmar et al., 2005). The first reaction of denitrification, is carried out by the periplasmic Mo-containing nitrate reductase (Delgado et al., 2003).

Despite the important role they play in nature, especially in the biogeochemical cycle of $\mathrm{N}$, are unknown mechanisms involved in the transport of Mo in the rhizobia. modABC genes of $B$. japonicum have been described and some mutants $\left(\bmod A^{-}\right.$and $\left.\bmod B^{-}\right)$have been obtained and characterized mostly under free living conditions (Delgado et al., 2006),. For this reason, the aim of this work was to study the effect of inoculation of soybean plants with strains affected in the Mo transport.

\section{MATERIALS AND METHODS}

\section{Bacterial strains and growth conditions}

The wild-type strain $B$. japonicum USDA110 (U. S. Department of Agriculture, Beltsville, MD) was used in this study. Yeast extract/mannitol (YEM) 
medium (Vincent, 1974) was used for routine cultures of this bacterium. Anaerobic cultures were kept in YEM medium supplemented with $10 \mathrm{mM}$ $\mathrm{KNO}_{3}$ (YEMN) in completely filled, rubber-stoppered serum bottles. Sometimes, the cultures were kept in Bergersen's minimum medium (Bergersen, 1977), in which glutamate was substituted by $10 \mathrm{mM} \mathrm{KNO} \mathrm{KN}_{3}(\mathrm{BN})$. All these media were prepared with MilliQ water and high-quality chemical products. When required, $\mathrm{Na}_{2} \mathrm{MoO}_{4} \cdot 2 \mathrm{H}_{2} \mathrm{O}$ and $\mathrm{K}_{2} \mathrm{SO}_{4}$ were added to the medium.

The selective capacity of culture media was obtained adding some antibiotics in the following concentrations $\left(\mu \mathrm{g} \mathrm{mL}{ }^{-1}\right)$ : spectinomycin, 200; streptomycin, 200; kanamycin, 200 and tetracycline, 100. E. coli strains were cultured in Luria-Bertani (LB) medium (Miller, 1972) at $37{ }^{\circ} \mathrm{C}$. E. coli DH5 $\alpha$ (Stratagene) was used as host in standard cloning procedures, and $E$. coli S17-1 (Simon et al., 1983) was used as the donor in conjugative plasmid transfer, The antibiotics used were $(\mu \mathrm{g}$ $\mathrm{mL}^{-1}$ ): ampicillin, 200; streptomycin, 20; spectinomycin, 20; kanamycin, 25 and tetracycline, 10.

Stewart (1988) described most chlorate-resistant cells show mutations affecting molybdenum uptake or its metabolism. On the other hand, he determined that the mutation of $E$. coli strains chlorate-resistant can be suppressed increasing the Mo concentration in the culture medium. Then, chlorate-resistant mutants of wildtype B. japonicum USDA110 were isolated following random mutagenesis Tn5-mob using of suicide plasmid pSUP2021 (Simon et al., 1983). So, they were obtained kanamycin-resistant transconjugants, these were replicated onto YEMN medium containing $15 \mathrm{mM}$ $\mathrm{KClO}_{3}$. One of the chlorate-resistant mutants obtained (B. japonicum 0507), unable to grow in aerobic or anaerobic conditions using nitrate as unique nitrogen source or respiratory substrate, respectively, was selected. Sequence analysis of the cloned DNA from this mutant strain revealed that, the transposon was inserted in an ORF that showed homology with $\operatorname{modB}$ genes from other bacteria (mainly Sinorhizobium meliloti). Chromosomal and plasmid DNA isolations, restriction enzyme digestions, agarose gel electrophoresis, ligations, E. coli transformations and sequencing, were performed according to standard protocols (Sambrook, Fritsch and Maniatis, 1989). So, the modABC genes of $B$. japonicum USDA110, were identified (Delgado et al., 2006).

Performing gene-directed mutagenesis by inserting of $\Omega \mathrm{Spc} / \mathrm{Sm}$ interposon of $\mathrm{pHP} 45 \Omega$, the $\bmod A$ gene was mutated (Delgado et al., 2006). This mutant was designated as B. japonicum 0512 .

\section{Plant growth conditions}

Soybean (Glycine max L. Merr., cv. Williams) seeds were surface-sterilized with $96 \%$ ethanol $(\mathrm{v} / \mathrm{v})$ for $30 \mathrm{~s}$, immersed in $\mathrm{H}_{2} \mathrm{O}_{2}(15 \%, \mathrm{v} / \mathrm{v})$ for $8 \mathrm{~min}$, then washed five times thoroughly in sterile water and germinated in darkness at $28^{\circ} \mathrm{C}$, during 2 or 3 days. Selected seedlings were planted in sterile Leonard jar assemblies filled with vermiculite.

For determination the effect that mutations in $\bmod A$ and $\bmod B$ genes could have on nitrogen fixation in the symbiosis B. japonicum-soybean, plants (two per jar) were inoculated at sowing with $1 \mathrm{~mL}$ cell suspension (approx. $10^{8}$ cells per seed) of a single bacterial strain (USDA110, 0507 and 0512 of $B$. japonicum). Plants were grown for 42 days, in a nitrogen-free nutrient solution 
(Rigaud and Puppo, 1975), prepared by using MilliQ water and high-quality chemical products, so that the plant growth depended only on the $\mathrm{N}_{2}$ fixation. Depending on the experiment, the solution was supplemented or not supplemented with $0.2,0.4,0.8$ and 1.2 $\mu \mathrm{M}$ of Mo. The sulfate concentration in the mineral solution used for plant growth was 3.5 or $10 \mathrm{mM}$. For determination the effect of cysteine on the requirements of Mo, a mineral solution with $3.5 \mathrm{mM}$ of sulfate, supplemented or not supplemented with $0.4 \mu \mathrm{M}$ Mo and 1.6 $\mathrm{mM}$ cysteine.

Plants were grown under controlled light conditions $\left(500 \mu \varepsilon \mathrm{m}^{-2} \mathrm{x} \mathrm{s}, 400-700\right.$ $\mathrm{nm}$ of wavelength), temperature $\left(25^{\circ} \mathrm{C} / 17^{\circ} \mathrm{C}\right.$, day/night), relative humidity (65\%), The photoperiod light/dark was 16 $\mathrm{h} / 8 \mathrm{~h}$ (day/night).

\section{Analytical determinations}

The ability to fix $\mathrm{N}_{2}$ was determined by acetylene reduction to ethylene: the acetylene-dependent ethylene production was assayed by gas chromatography on detached root systems excised at the cotyledonary node, essentially as described by Mesa et al. (2004). Plant and nodule dry weight, and tissue $\mathrm{N}$ (Kjeldahl analysis) were assayed on plant samples that had been heated at $60^{\circ} \mathrm{C}$ for $48 \mathrm{~h}$. The leghemoglobin content of soybean nodules was determined by fluorimetry, as described previously (Delgado et al., 1993). The soluble protein concentration in extract cytosolic of nodules was estimated by using the Bio-Rad assay, with Bovine Serum Albumin (Sigma), as standard.

In the statistical analysis for comparisons of the average value of measurements of all parameters studied, the Statgraphics Plus Program (Fisher test), was used.

\section{RESULTS AND DISCUSSION}

\section{Effect of soybean plants inoculation with mod mutants on nitrogenase activity}

In $B$. japonicum has been shown the presence of $\bmod A B C$ genes encoding a high-affinity transporter for Mo, so, consequently, mod mutants were unable to grow when these were cultured in minimal medium $(\mathrm{BN})$, without addition of Mo (Delgado et al., 2006).

Although our results showed no significant differences between the number of nodules formed by each of the strains $(71 \pm 4)$ or between their dry weight $(0.184 \pm 0.006 \mathrm{~g})$, the values of nitrogenase activity, dry weight and nitrogen content of plants inoculated with the wild-type strain were significantly higher than $(p \leq 0.05)$ those inoculated with the mutant strains 0507 and 0512 when soybean plants were grown in the presence of concentrations of Mo $\leq 0.4$ $\mu \mathrm{M}$. However, these differences were not observed when Mo concentrations were $\geq$ $0.8 \mu \mathrm{M}$ (Table 1).

These results have relation with those reported by Delgado et al. (2006), they indicated that the 0512 mutant strain regains the ability to grow under freeliving conditions when was grown on minimal medium (BN) supplemented with Mo concentrations $\geq 0.35 \mu \mathrm{M}$. On the other hand, the concentration of leghemoglobin and protein in the cytosol of the nodules of plants grown without addition of Mo and inoculated with the mutant strains 0507 and 0512 were about $61 \%$ and $25 \%$ respectively, lower than ( $p$ $\leq 0.05)$ the values determined in nodules of plants inoculated with the wild-type strain (Table 2). These differences were not observed when the nutrient solution was supplemented with $0.8 \mu \mathrm{M}$ 
Mo (Table 2). Since that nitrogenase is a molybdoenzyme, it seems logical the existence of differences in the symbiotic parameters of the plants, due to the difficulty of the mutant strains 0507 and 0512, either for the synthesis or activity of this enzyme.

Table 1. Acetylene reduction activity (ARA), plant dry weight (PDW) and nitrogen content $[\mathrm{N}]$ of soybean plants inoculated with B. japonicum wild-type and their mutants 0507 and 0512 and, cultured in presence of different Mo concentrations.

\begin{tabular}{|c|c|c|c|c|c|c|c|c|c|}
\hline \multirow{3}{*}{$\begin{array}{c}\text { Mo } \\
\text { concentration } \\
(\mu \mathrm{M})\end{array}$} & \multicolumn{9}{|c|}{ B. japonicum strain } \\
\hline & \multicolumn{3}{|c|}{ USDA110 } & \multicolumn{3}{|c|}{0507} & \multicolumn{3}{|c|}{0512} \\
\hline & ARA & PDW & {$[\mathbf{N}]$} & ARA & PDW & {$[\mathbf{N}]$} & ARA & PDW & {$[\mathbf{N}]$} \\
\hline 0.0 & $266 \mathbf{a}$ & $2.4 \mathbf{a}$ & $76 \mathbf{a}$ & $101 \mathbf{b}$ & $1.5 \mathbf{b}$ & $40 \mathbf{b}$ & $100 \mathbf{b}$ & $1.7 \mathbf{b}$ & $41 b$ \\
\hline 0.2 & $414 \mathbf{a}$ & $3.0 \mathbf{a}$ & $76 \mathbf{a}$ & $237 \mathbf{b}$ & $2.0 \mathrm{~b}$ & $46 b$ & $248 \mathbf{b}$ & $2.1 \mathbf{b}$ & $48 b$ \\
\hline 0.4 & $395 \mathbf{a}$ & $2.9 \mathbf{a}$ & $77 \mathbf{a}$ & $258 \mathbf{b}$ & $2.2 \mathbf{b}$ & $47 \mathrm{~b}$ & $260 \mathbf{b}$ & $2.3 \mathbf{b}$ & $50 \mathrm{~b}$ \\
\hline 0.8 & $400 \mathbf{a}$ & $2.9 \mathbf{a}$ & $79 \mathbf{a}$ & $397 \mathbf{a}$ & $2.9 \mathbf{a}$ & $78 \mathbf{a}$ & $393 \mathbf{a}$ & $2.7 \mathbf{a}$ & $77 \mathbf{a}$ \\
\hline 1.2 & $395 \mathbf{a}$ & $3.0 \mathbf{a}$ & $78 \mathbf{a}$ & $388 \mathbf{a}$ & $2.9 \mathbf{a}$ & $79 \mathbf{a}$ & $380 \mathbf{a}$ & $2.8 \mathbf{a}$ & $78 \mathbf{a}$ \\
\hline
\end{tabular}

The units of ARA were $\mu$ mol ethylene reduced $\mathrm{g}^{-1}$ nodule dry weight $\mathrm{h}^{-1}$; the units of PDW are $g$ plant ${ }^{-1}$ and the units of $[\mathrm{N}]$ are $\mathrm{mg}$ plant ${ }^{-1}$. Values in individual columns followed by the same letter are not significantly different at $p \leq 0.05,(\mathrm{n}=12)$.

Table 2. Leghemoglobin ( $\mathrm{Lb})$ and protein contents in nodules of soybean plants inoculated with B. japonicum wild-type and their mutants 0507 and 0512 and, cultured in presence of different Mo concentrations.

\begin{tabular}{lcccc}
\hline \multirow{2}{*}{$\begin{array}{c}\text { B. japonicum } \\
\text { strain }\end{array}$} & \multicolumn{5}{c}{ Mo concentration $(\boldsymbol{\mu M})$} \\
\cline { 2 - 5 } & $\mathrm{Lb}$ & Protein & Lb & Protein \\
\cline { 2 - 5 } & $5.69 \mathbf{a}$ & $23.44 \mathbf{a}$ & $6.52 \mathbf{a}$ & $24.48 \mathbf{~ a}$ \\
USDA110 & $2.19 \mathbf{b}$ & $16.89 \mathbf{b}$ & $6.61 \mathbf{~ a}$ & $24.32 \mathbf{~ a}$ \\
0507 & $2.23 \mathbf{~ b}$ & $17.46 \mathbf{b}$ & $6.81 \mathbf{~ a}$ & $25.01 \mathbf{~ a}$ \\
0512 & &
\end{tabular}

The units of $\mathrm{Lb}$ and protein content were $\mathrm{mg} \mathrm{g}^{-1}$ nodule fresh weight. Values in individual columns followed by the same letter are not significantly different at $p \leq 0.05,(n=12)$.

Effect of sulfate on Mo transport in the B. japonicum-soybean symbiosis

Because the defects in the efficiency of $\mathrm{N}_{2}$ fixation produced in the mutant strains disappeared when it was added Mo $(\geq 0.8$ $\mu \mathrm{M})$ to the mineral solution of Rigaud and Puppo (1975), it is evident that $B$. japonicum possesses the system codified by mod genes and another transporter 
system of Mo. In Clostridium pasteurianum (Elliot and Mortenson, 1975) and Escherichia coli (Lopez et al., 1993), has been shown that sulfate competitively inhibits the Mo transport and that in E. coli, the Mo can be incorporated into the cell through the sulfate transport system (Rosentel et al., 1995). Moreover, in B. japonicum has been observed that the addition of sulfate suppresses its transport (Ohta et al., 1971; Kredich, 1987), and it was necessary an increase in the Mo concentration for anaerobic growth of the mutant strain 0512, under free-living conditions (Delgado et al., 2006).

To investigate the role of sulfate on Mo transport in the B. japonicum-soybean symbiosis, a mineral solution supplemented or not supplemented with $0.8 \mu \mathrm{M}$ Mo, was used and, in each case, the solution was supplemented with 3.5 or $10 \mathrm{mM}$ sulfate. Independently of the strain or the treatment used, there were no significant differences in the number $(73$ $\pm 4)$ and the dry weight of nodules ( 0.180 $\pm 0.007 \mathrm{~g}$ ) formed by each strain. Similarly, there were not differences in the dry weight and the $\mathrm{N}$ content between plants nodulated with any of the strains, regardless of the sulfate concentration used, when soybean plants grew up with a solution was containing $0.8 \mu \mathrm{M}$ Mo (Table 3). By contrast, in plants inoculated with the wild-type strain and grown without the addition of Mo, the dry weight and the nitrogen content decreased about $17 \%$ and $20 \%$, respectively, when the mineral solution was containing 3.5 $\mathrm{mM}$ or $10 \mathrm{mM}$ sulfate (Table 3 ). When plants were inoculated with the mutant strains and grown without the addition of Mo but supplemented with $3.5 \mathrm{mM}$ sulfate, the decrease in dry weight and the nitrogen content was approximately $37 \%$ and $46 \%$, respectively (Table 3 ).

Table 3. Plant dry weight (PDW) and nitrogen content $[\mathrm{N}]$ of soybean plants inoculated with $B$. japonicum wild-type and their mutants 0507 and 0512 and, cultured in presence of different Mo and sulfate concentrations.

\begin{tabular}{|c|c|c|c|c|c|}
\hline \multirow{3}{*}{$\begin{array}{l}\text { B. japonicum } \\
\text { strain }\end{array}$} & \multirow{3}{*}{$\begin{array}{c}\text { Sulphate } \\
\text { concentration } \\
(\mathbf{m M})\end{array}$} & \multicolumn{4}{|c|}{ Mo concentration $(\boldsymbol{\mu M})$} \\
\hline & & \multicolumn{2}{|c|}{$\mathbf{0}$} & \multicolumn{2}{|c|}{0.8} \\
\hline & & PDW & {$[\mathrm{N}]$} & PDW & {$[\mathrm{N}]$} \\
\hline \multirow{2}{*}{ USDA110 } & 3.5 & $2.5 \mathbf{a}$ & $63 \mathrm{a}$ & $3.0 \mathbf{a}$ & $79 \mathbf{a}$ \\
\hline & 10 & $2.4 \mathbf{a}$ & $61 \mathbf{a}$ & $3.1 \mathrm{a}$ & $80 \mathbf{a}$ \\
\hline \multirow{2}{*}{0507} & 3.5 & $1.8 \mathrm{~b}$ & $40 \mathrm{~b}$ & $2.8 \mathrm{a}$ & $78 \mathbf{a}$ \\
\hline & 10 & $1.0 \mathrm{c}$ & $30 \mathrm{c}$ & $2.7 \mathbf{a}$ & $79 \mathbf{a}$ \\
\hline \multirow{2}{*}{0512} & 3.5 & $1.8 \mathrm{~b}$ & $41 \mathrm{~b}$ & $2.8 \mathbf{a}$ & $77 \mathbf{a}$ \\
\hline & 10 & $1.1 \mathrm{c}$ & $31 \mathbf{c}$ & $2.9 \mathbf{a}$ & $77 \mathbf{a}$ \\
\hline
\end{tabular}

The units of PDW are $g$ plant ${ }^{-1}$ and the units of $[\mathrm{N}]$ are $\mathrm{mg}$ plant $^{-1}$. Values followed by the same letter are not significantly different at $p \leq 0.05,(\mathrm{n}=12)$. 
Up to $63 \%$ and $59 \%$ decrease in dry weight and nitrogen content was detected when plants were inoculated with the mutant strains and grown in the absence of Mo and presence of $10 \mathrm{mM}$ sulfate (Table 3). Similarly, the values of acetylene reduction to ethylene and leghemoglobin $(\mathrm{Lb})$ in plant nodules formed by the 0507 or 0512 mutants, grown in absence of Mo and in presence of $3.5 \mathrm{mM}$ sulfate, were reduced by nearly $40 \% 20 \%$, respectively, compared with plants supplemented with Mo (Table 4). The addition of $10 \mathrm{mM}$ sulfate to the Mo-deficient nutrient solution, decreased the nitrogenase activity and $\mathrm{Lb}$ content around $60 \%$ and $39 \%$, respectively, compared with the values observed in plants grown in a Mo-containing solution (Table 4).

Table 4. Acetylene reduction activity (ARA) and leghemoglobin (Lb) content in nodules of soybean plants inoculated with B. japonicum wild-type and their mutants 0507 and 0512 and, cultured in presence of different Mo and sulfate concentrations.

\begin{tabular}{lcccccc}
\hline \multirow{2}{*}{$\begin{array}{c}\text { B. japonicum } \\
\text { strain }\end{array}$} & $\begin{array}{c}\text { Sulphate } \\
\text { concentration } \\
(\mathbf{m M})\end{array}$ & \multicolumn{5}{c}{ Mo concentration $(\boldsymbol{\mu M})$} \\
\cline { 3 - 7 } & 3.5 & ARA & Lb & ARA & Lb \\
\cline { 3 - 7 } USDA110 & 10 & $336 \mathbf{a}$ & $9.5 \mathbf{a}$ & $398 \mathbf{a}$ & $9.2 \mathbf{a}$ \\
& 3.5 & $226 \mathbf{b}$ & $8.9 \mathbf{b}$ & $395 \mathbf{a}$ & $8.9 \mathbf{a}$ \\
0507 & 10 & $149 \mathbf{c}$ & $4.9 \mathbf{c}$ & $396 \mathbf{a}$ & $9.1 \mathbf{a}$ \\
\cline { 2 - 7 } & 3.5 & $232 \mathbf{b}$ & $6.7 \mathbf{b}$ & $289 \mathbf{a}$ & $9.2 \mathbf{a}$ \\
0512 & 10 & $151 \mathbf{c}$ & $5.0 \mathbf{c}$ & $290 \mathbf{a}$ & $8.9 \mathbf{a}$ \\
\hline
\end{tabular}

The units of ARA were $\mu$ mol ethylene reduced $\mathrm{g}^{-1}$ nodule dry weight $\mathrm{h}^{-1}$ and the units of Lb content were $\mathrm{mg} \mathrm{g}^{-1}$ nodule fresh weight. Values in individual columns followed by the same letter are not significantly different at $p \leq 0.05,(\mathrm{n}=12)$.

\section{Effect of the cysteine on the requirements of Mo}

As already indicated, mutant strains do not grow in minimal medium $(\mathrm{BN})$, supplemented with Mo concentrations $<0.35 \mu \mathrm{M}$ (Delgado et al., 2006) and values of nitrogenase activity, dry weight and nitrogen content of plants inoculated with wild-type strain were significantly higher $(p \leq 0.05)$ to that of those inoculated with the mutant strains when soybean was grown in the presence of concentrations $\leq 0.4 \mu \mathrm{M}$ Mo (Table 1).
The use of a nutrient solution of soybean plants with $0.4 \mu \mathrm{M}$ Mo, $3.5 \mathrm{mM}$ sulfate and $1.6 \mathrm{mM}$ cysteine, restored the wildtype phenotype of the 0507 and 0512 mutant strains because there was no difference between the values of activity nitrogenase, dry weight or $\mathrm{N}$ content of plants inoculated with the wild-type strain and the values of plants inoculated with the mutant strains (Table 5).

These results have relation with those reported by Ugalde et al. (1985), who described that the addition of cysteine to the culture medium suppresses the effects 
Table 5. Acetylene reduction activity (ARA), plant dry weight (PDW) and nitrogen content $[\mathrm{N}]$ of soybean plants inoculated with wild-type B. japonicum and their 0507 and 0512 mutants and, cultured in presence of Mo $(0.4 \mu \mathrm{M}), \mathrm{MgSO} 4(3.5 \mathrm{mM})$ and absence or presence of cysteine $(1.6 \mathrm{mM})$.

\begin{tabular}{ccccccccccc}
\hline & \multicolumn{10}{c}{ B. japonicum strain } \\
Cysteíne & $\mathbf{1 . 6} \mathbf{~ m M})$ & \multicolumn{1}{c}{ USDA110 } & \multicolumn{10}{c}{$\mathbf{0 5 0 7}$} & \multicolumn{3}{c}{$\mathbf{0 5 1 2}$} \\
\cline { 2 - 12 } & ARA & PDW & {$[\mathbf{N}]$} & ARA & PDW & {$[\mathbf{N}]$} & ARA & PDW & {$[\mathbf{N}]$} \\
\hline Absent & $266 \mathbf{a}$ & $2.4 \mathbf{a}$ & $76 \mathbf{a}$ & $101 \mathbf{b}$ & $1.5 \mathbf{b}$ & $40 \mathbf{b}$ & $100 \mathbf{b}$ & $1.7 \mathbf{b}$ & $41 \mathbf{b}$ \\
Present & $324 \mathbf{a}$ & $2.7 \mathbf{a}$ & $78 \mathbf{a}$ & $337 \mathbf{b}$ & $2.9 \mathbf{b}$ & $79 \mathbf{b}$ & $335 \mathbf{b}$ & $2.8 \mathbf{b}$ & $78 \mathbf{b}$ \\
\hline
\end{tabular}

The units of ARA were $\mu$ mol ethylene reduced $\mathrm{g}^{-1}$ nodule dry weight $\mathrm{h}^{-1}$; the units of PDW are g plant ${ }^{1}$ and the units of $[\mathrm{N}]$ are $\mathrm{mg} \mathrm{plant}^{-1}$. Values in individual columns followed by the same letter are not significantly different at $\mathrm{p} \leq 0.05,(\mathrm{n}=12)$.

of the mutation of modABC genes in Klebsiella pneumoniae strains.

As it has been observed in $B$. japonicum, the addition of sulfate causes the suppression of its transport (Ohta et al., 1971; Kredich, 1987), as in S. typhimurium (Dreyffus and Pardee, 1966) and E. coli (Rosentel et al., 1995), if the cysteine inhibits the sulfate transport, and mutant strains grew in the presence of cysteine and the symbiotic parameters were similar to those of the wild-type strain, it is possible the existence of a third transport system of $\mathrm{Mo}$ in $B$. japonicum, that would be functional in the presence of high sulfate concentrations.

\section{CONCLUSIONS}

The mutation in $\bmod A$ or $\bmod B$ genes of Bradyrhizobium japonicum did not affect its ability to form nodules on soybean plants, but decreased the ability to fix atmospheric nitrogen.

$\bmod A$ and $\bmod B$ genes of Bradyrhizobium japonicum are required for a fully effective $B$. japonicum-soybean symbiosis under Mo-limiting conditions.
Bradyrhizobium japonicum possesses, at least, three Mo transport systems, a highaffinity ABC-type transport system encoded by the modABC genes, the second, probably, a sulfate transporter that allows the incorporation of Mo with lower efficiency, and a third, which would only act under excess sulfate conditions.

\section{ACKNOWLEDGEMENTS}

This work was supported by grants CGL2006-06870/BOS Project of the Ministerio de Educación y Ciencia (MEC) and the Junta de Andalucía (PAI/CVI275). A. Tresierra-Ayala was the recipient of a fellowship from Agencia Española de Cooperación Internacional (AECI). El Consejo Nacional de Ciencia, Tecnología e Innovación Tecnológica (CONCYTECPerú) is also acknowledged.

\section{REFERENCES}

Arnau, J. 2009. La soja. (Disponible en: http://alimentacion.interbusca.com/alimentos/prot eina-vegetal/soja-1.html, verificado 10/jun/2010). 
Bedmar, E.J., Robles, E.F. and Delgado, M.J. 2005. The complete dentrification pathway of symbiotic $\mathrm{N}$-fixing bacteria Bradyrhizobium japonicum. Biochemical Society Transactions 1, 11-16.

Bergersen, F.J. 1977. A Treatise on Dinitrogen Fixation. In: Hardy, R.W. and Silver, W. (eds), Biology, section III. Willey. Nueva York, pp: 519-556.

Delgado, M.J., Garrido, J.M., Ligero, F. and Lluch, C. 1993. Nitrogen fixation and carbon metabolism by nodules and bacteroids of pea plants under sodium chloride stress. Physiologia Plantarum 89, 824-829.

Delgado, M.J., Bonnard, N., Tresierra-Ayala, A., Bedmar, E.J. and Müller, P. 2003. The Bradyrhizobium japonicum napEDABC genes encoding the periplasmic nitrate reductase are essential for nitrate respiration. Microbiology 149, 3395-3403.

Delgado, M.J., Tresierra-Ayala, A., Talbi, C., Bedmar, E.J. 2006. Functional characterization of the Bradyrhizobium japonicum modA and $\bmod B$ genes involved in molybdenum transport. Microbiology 152, 199-207.

Dreyfuss, J. and Pardee, A.B. 1966. Regulation of sulfate transport in Salmonella typhimurium. Journal of Bacteriology 91, 2275-2280.

Elliott, B.B. and Mortenson, L.E. 1975 Transport of molybdate by Clostridium pasteurianum. Journal of Bacteriology 124, 1295-1301

Grunden, A.M. and Shanmugam, K.T. 1997. Molybdate transport and regulation in bacteria. Archives of Microbiology 168, 345-354.

Kertesz, M.A. 2001. Bacterial transporters for sulphate and organosulfur compounds. Research in Microbiology 152, 279-290.

Kredich, N.M. 1987. Biosynthesis of cysteine In: F. C. Neidhardt, F.C.; Ingraham, J.L.; Low, K.B.; Magasanik, B.; Schaechter, M. and Umbarger, H.E. (eds). Escherichia coli and Salmonella typhimurium: Cellular and Molecular Biology, Washington, DC: American Society for Microbiology, pp: 419-428.

Lawson, D.M. and Smith, B.E. 2002 Molybdenum nitrogenases: a crystallographic and mechanistic view. Metal Ions in Biological Systems 39, 75-119.
Lopez, G., Bastidas, M. and Dubourdieu, M. 1993. Molybdenum uptake in Escherichia coli K12. Journal of General Microbiology 139, 18691875 .

Mesa, M., Alché, J.D., Bedmar, E.J. and Delgado, M.J. 2004. Expression of nir, nor and nos dentrification genes from Bradyrhizobium japonicum in soybean root nodules. Physiologia Plantarum 120, 205-211.

Miller, J.H. 1972. Experiments in Molecular Genetics. Cold Spring Harbor, NY: Cold Spring Harbor Laboratory.

Ohta, N., Galsworthy, P.R. and Pardee, A.B. 1971. Genetics of sulfate transport by Salmonella typhimurium. Journal of Bacteriology 105, 1053-1062.

Pau, R.N. and Lawson, D.M. 2002. Transport, homeostasis, regulation, and binding of molybdate and tungstate to proteins. Metal Ions in Biological Systems 39, 31-74.

Rigaud, J. and Puppo, A. 1975. Indole-3-acetic catabolism by soybean bacteroids. Journal of General Microbiology 88, 223-228.

Rosentel, J.K., Healy, F., Maupin-Furlow, J.A., Lee, J.H. and Shanmugam, K.T. 1995. Molybdate and regulation of mod (molybdate transport), $f d h F$, and hyc (formate hydrogenlyase) operons in Escherichia coli. Journal of Bacteriology 177, 4857-4864.

Sambrook, J., Fritsch, E.F. and Maniatis, T. 1989. Molecular Cloning: a Laboratory Manual. Cold Spring Harbor, NY: Cold Spring Harbor Laboratory.

Self, W.T., Grunden, A.M., Hasona, A. and Shanmugam, K.T. 2001. Molybdate transport. Research in Microbiology 152, 311-321.

Simon, R.; Priefer, U. and Pühler, A. 1983. A broad host range mobilization system for in vivo genetic engineering transposon mutagenesis in Gram negative bacteria. Biotechnology 1, 784791.

Sirko, A., Hryniewicz, M., Hulanicka, D. and Böck, A. 1990. Sulfate and thiosulfate transport in Escherichia coli K-12.: nucleotide sequence and expression of the cysTWAM gene cluster. Journal of Bacteriology 172, 3351-3357.

Stewart, V. and MacGregor, C.H. 1982. Nitrate reductase in Escherichia coli K-12: involvement 
of chlC, chlE, and chlG loci. Journal of Bacteriology 151, 788-799.

Stewart, V. 1988. Nitrate respiration in relation to facultative metabolism in enteric bacteria. Microbiological Reviews 52, 190-232.

Trudinger, P.A. and Loughlin, R.E. 1982. Metabolism of simple sulfur compounds. In: Neuberger, A. and Van Deenen, L. (eds) Aminoacid metabolism and sulfur metabolism. Vol 19A. Comprehensive biochemistry. Elsevier Science Publishing Co., Inc., New York, pp: 165256.
Ugalde, R.A., Imperial, J., Shah, V.K. and Brill, W. 1985. Biosynthesis of the ironmolybdenum cofactor and the molybdenum cofactor in Klebsiella pneumoniae: effect of sulfur source. Journal of Bacteriology 164, 10811087.

Vincent, J.M. 1974. Root-nodule symbioses with Rhizobium. En: Quispel, A. (ed). The Biology of Nitrogen Fixation. New York: American Elsevier Publishing Company, pp: 265-341. 